Marcin Warchoła

ORCID: 0000-0003-4738-0672

Państwowa Wyższa Szkoła Techniczno-Ekonomiczna im. ks. Bronisława Markiewicza w Jarosławiu

\section{Rola rodziny w procesie wychowania do czasu wolnego, rekreacii i turystyki}

\author{
The Role of the Family in the Education \\ for Free Time, Recreation and Tourism
}

\begin{abstract}
ABSTRAKT
Dbanie o wysoki poziom uczestnictwa w różnych formach kultury fizycznej przez dzieci i młodzież wydaje się istotnym elementem przygotowania ich do dorosłego życia, a tym samym do funkcjonowania w społeczeństwie.

Niniejszy artykuł prezentuje rozważania na temat roli rodziny w procesie wychowania człowieka do świadomego uczestnictwa w kulturze fizycznej, przejawiającego się aktywnościq fizycznq w czasie wolnym. Zjawisko czasu wolnego rozpatrywano w kontekście funkcji wychowawczych, w dwóch perspektywach, ti. wychowania do czasu wolnego oraz wychowania w czasie wolnym. Spośród aktywności wolnoczasowych człowieka, społecznie pożq̨anych a posiadajqcych udowodnione w licznych badaniach naukowych walory wychowawcze, wybrano rekreację i turystykę. Dlatego też na poczq̨tku rozważań zaprezentowano analizę potencjału wychowawczego tych trzech zjawisk. Następnie omówiono istotę i etapy realizacji procesu wychowania do czasu wolnego, rekreacji i turystyki. Przedstawiono również wnioski z badań różnych autorów dotyczqce wpływu rodziny na poziom aktywności rekreacyjnej i turystycznej w czasie wolnym.
\end{abstract}

SLOWA KLUCZOWE wychowanie, rodzina, czas wolny, rekreacja, turystyka

\section{KEYWORDS}

upbringing, family, leisure, recreation, tourism

SPI Vol. 22, 2019/2

ISSN 2450-5358

e-ISSN 2450-5366

DOI: 10.12775/SPI.2019.2.006

Nadesłano: 01.10.2018 Zaakceptowano: 21.05.2019

Artykuły i rozprawy 
Artykuł jest próbq wskazania pewnych kluczowych aspektów tego klasycznego już zagadnienia, w szczególności w kontekście zaobserwowanych zmian $w$ sposobach realizacji czasu wolnego przez najmłodsze pokolenie. Zauważalna jest bowiem przewaga zajęć sedenteryjnych nad zajęciami zwiqzanymi z aktywnościq ruchowq, wynikająca z postępu technicznego, w tym komputeryzacji i rozwoju mediów społecznościowych.

\section{ABSTRACT}

Caring for a high level of participation in various forms of physical culture by children and youth seems to be an essential element of preparing them for adult life, and thus for functioning in society.

This article presents reflections on the role of the family in the process of educating people to consciously participate in physical culture, manifested by physical activity in their free time. The phenomenon of free time was considered in the context of educational functions, in two perspectives, i.e. education to free time and education in free time. Recreation and tourism have been chosen from among human leisure activities, which are socially desirable and have proven educational values in numerous scientific studies. Therefore, at the beginning of the discussion, the analysis of the educational potential of these three phenomena was presented. Then, the essence and stages of the implementation of the education process to free time, recreation and tourism were discussed. Conclusions from the research of various authors concerning the influence of the family on the level of recreational and tourist activity in leisure time are also presented.

The article is an attempt to indicate some main aspects of this classic issue, especially in the context of observed changes in the ways of the realization of free time by the youngest generation. The dominance of sedentary activities over physical activities is noticeable, resulting from technical progress, including computerization and the development of social media. 


\section{Wstęp}

Wszystko, co człowiek wewnętrznie posiada, powstaje jako dzieło wychowania. Przez wszechstronny rozwój przyczynia się ono do zapewnienia maksymalnych warunków uszczęśliwienia jednostek ludzkich, dając im wykształcenie i przygotowanie życiowe, rozumienie świata i życia, zadowolenie z pracy i miłości wzajemnej, a także, na co zwraca uwagę Kunowski, radość kulturalnego spędzania wolnego czasu ${ }^{1}$.

Czas wolny stwarza specyficzną płaszczyznę ludzkiej działalności, związaną z własnymi korzyściami, włączając w to możliwości wyboru działań, rozwoju, satysfakcji, zadowolenia i szczęścia. Obejmuje te formy wyrazu i aktywności, którego elementy wynikają z fizycznej natury oraz są wspólne z potrzebami intelektualnymi, socjalnymi, artystycznymi i duchowymi ${ }^{2}$. Bowiem czas wolny, według T. Wolańskiej, to „życie w relatywnej wolności od zewnętrznych przymusów kulturowych i środowiska zewnętrznego. Będąc zdolnym do działania wypływającego z własnych zamiłowań, uznajemy je jako wartościowe i stanowią podstawę dla naszych przekonań”3. Dlatego te ż proces wychowania dzieci i młodzieży do racjonalnego wykorzystania czasu wolnego traktowany jest obecnie jako edukacja dla przyszłości ${ }^{4}$.

Bardzo ważne z punktu widzenia pedagogiki jest rozpatrywanie zjawiska czasu wolnego dzieci i młodzieży w dwóch perspektywach:

a) wychowania do czasu wolnego, czyli do racjonalnego gospodarowania nim, efektywnego realizowania jego funkcji w interesie własnym i otoczenia;

1 Por. S. Kunowski, Podstawy wspótczesnej pedagogiki, Warszawa 1996, s. 23.

2 Por. J. Ożdziński, Nowa rola czasu wolnego i rekreacji w Europie $i$ w Polsce, w: Rekreacja, turystyka, kultura, red. B. Marciszewska, J. Ożdziński, Gdańsk 2004, s. 15.

3 T. Wolańska, Leksykon. Sport dla wszystkich - rekreacja ruchowa, Warszawa 1997, s. 17.

4 Por. A. Wartecka-Ważyńska, Turystyka mtodzieży i jej uwarunkowania, Poznań 2007, s. 9. 
b) wychowania w czasie wolnym, to znaczy w sytuacjach wychowawczych, które noszą znamiona dobrowolności, niekomercyjności i są źródłem podmiotowej satysfakcji ${ }^{5}$.

Natomiast K. Przecławski rozpatrując efektywność działań w zakresie pedagogiki czasu wolnego stwierdza, że konieczne jest spełnienie m.in. następujących warunków:

- uznanie, że organizacja czasu wolnego dzieci i młodzieży jest $\mathrm{z}$ wychowawczego punktu widzenia równie ważna, jak działalność dydaktyczna szkoły,

- rozwijanie samorządności dzieci i młodzieży, tzn. nie tylko organizowanie jej czasu przez dorosłych, ale kształtowanie umiejętności samodzielnego organizowania czasu przez młodzież,

- preferowanie form aktywnego (np. turystyka) i twórczego spędzania czasu wolnego ${ }^{6}$.

Jednak obserwacja życia codziennego i liczne badania empiryczne wskazują na niepokojące zjawisko. Okazuje się, że współczesny uczeń posiada za mało czasu do swojej dyspozycji. Poza tym ten krótki czas, którym dysponuje, często jest marnotrawiony na zajęcia pasywne, konsumpcyjne i na ogół niezdrowe, często nawet niebezpieczne i nieetyczne ${ }^{7}$.

Wśród wielu różnych ofert spędzania czasu wolnego istotny zbiór stanowią propozycje sformułowane przez zwolenników propagowania i rozpowszechniania rozmaitych postaci kultury fizycznej. Mają one, zdaniem J. Kosiewicza, charakter autoteliczny i są skierowane na doskonalenie własnej osoby ${ }^{8}$. Nie ulega dziś wątpliwości, że powszechnie dostępne, popularne, pozaszkolne formy kultury fizycznej stają się w świetle stwierdzonych zagrożeń cywilizacyjnych i potrzeb

5 Por. M. Czerepaniak-Walczak, Pedagogika czasu wolnego: schole w szkole i poza szkota, w: Rekreacja i czas wolny. Studia humanistyczne, red. R. Winiarski, Warszawa 2011, s. 217.

6 Por. K. Przecławski, Czas wolny dzieci i mtodzieży, w: Encyklopedia pedagogiczna, red. W. Pomykało, Warszawa 1993, s. 76.

7 Por. S. Toczek-Werner, Czas wolny ucznia - nowe wyzwanie dla dziatalności edukacyjnej w szkole, w: Edukacja jutra. XIII Tatrzañskie Seminarium Naukowe, red. K. Zaton, T. Koszyc, M. Sołtysik, Wrocław 2007, s. 285.

8 Por. J. Kosiewicz, Czas wolny i wolnośc wyboru, w: Turystyka i rekreacja. Wymiary teoretyczne i praktyczne, red. J. Kosiewicz, K. Obodyński, Rzeszów 2006, s. 217. 
edukacyjnych i rozwojowych dzieci i młodzieży nieodzownie koniecznym uzupełnieniem procesu wychowawczego?

Najlepszym niezaprzeczalnie sposobem wychowania do aktywnego stylu życia jest wychowanie w rodzinie. Przekazuje ona najtrwalsze, najsilniej internalizowane normy, wartości, sposoby postępowania. Rekreacja, turystyka czy sport w rodzinie stanowią podstawę zacieśnienia więzi rodzinnych, rozwijają i stymulują zdolności kreacyjne człowieka, stwarzają zaspokajają potrzeby aktywności fizycznej i zabawy dzieci z dorosłymi, podtrzymują i rozwijają sprawność fizyczną, umiejętności ruchowe i kondycję fizyczną członków rodziny ${ }^{10}$.

\section{Rodzina jako środowisko wychowawcze}

Środowiskiem wychowawczym stają się te wszystkie elementy składowe otoczenia jednostki, które zapewniają jej rozwój, które przyczyniają się do powstawania i utrwalania cech potrzebnych dla funkcjonowania i osiągania celów życiowych. Wszędzie tam, gdzie jednostka przyswaja sobie trwałe elementy wiedzy, sposoby działania, myślenia, odczuwania itp., tworzy sobie mniej lub więcej trwałe wyobrażenia o świecie, ludziach i wartościach, mamy do czynienia z procesem socjalizacji lub wychowania i te składniki środowiska, które te składniki wywołują, tworzą środowisko wychowawcze jednostki ${ }^{11}$.

W literaturze pedagogicznej rozróżniamy dwa rodzaje środowisk wychowawczych: intencjonalne i naturalne.

Środowiskiem wychowawczym intencjonalnym będzie środowisko społeczne celowo wydzielone (powołane) do oddziaływania wychowawczego. Wśród tego typu środowisk wyróżniamy następujące instytucje i placówki: szkoły, związki młodzieży, kluby, świetlice, ośrodki socjalne, domy społeczne, domy kultury, uniwersytety powszechne (ludowe), domy dziecka, rodzinne domy dziecka, rodziny

9 Por. A. Dąbrowski, Pozaszkolna kultura fizyczna mtodzieży - rzeczywistość a potrzeby i oczekiwania, Warszawa 1997, s. 35.

10 Por. I. Kiełbasiewicz-Drozdowska, Osobowościowe i spoteczne uwarunkowania rekreacji, w: Teoria i metodyka rekreacji. Zagadnienia podstawowe, red. I. Kiełbasiewicz-Drozdowska, W. Siwiński, Poznań 2001, s. 47.

11 Por. J. Szczepański, Środowisko wychowawcze, w: Encyklopedia pedagogiczna, red. W. Pomykało, Warszawa 1993, s. 820. 
zastępcze, domy wczasowe, kolonie i obozy, parki, ogrody jordanowskie, parki kultury i wypoczynku ${ }^{12}$.

Natomiast naturalnym środowiskiem wychowawczym nazywamy tę część środowiska wychowawczego, która funkcje dydaktyczne, opiekuńcze, społeczne, kulturalne, towarzyskie itp. pełni w sposób niezamierzony. Do naturalnych środowisk wychowawczych zaliczamy m.in.: rodzinę, zakład pracy, osiedle mieszkaniowe, społeczność wiejską, grupy nieformalne, środki masowego przekazu i inne ${ }^{13}$.

$\mathrm{Z}$ powyższego wynika, że rodzina jest jednym $\mathrm{z}$ najważniejszych składników środowiska wychowawczego.

Rodzina jest dla człowieka tzw. grupą podstawową, to znaczy grupą, z którą jest on bardzo ściśle związany znaczną częścią swej osobowości i ważnymi pełnionymi przez siebie rolami społecznymi. Jest także przeważnie dla niego tzw. grupą odniesienia, z którą świadomie i mocno identyfikuje się jako członek i reprezentant, współtworzy oraz przejmuje kultywowane w niej poglądy, postawy, obyczaje, wzory zachowania i postępowania ${ }^{14}$.

Wyróżniamy następujące funkcje rodziny, podzielone na cztery kategorie:

I. Funkcje biopsychiczne: 1) funkcja prokreacyjna, 2) funkcja seksualna;

II. Funkcje ekonomiczne: 1) funkcja materialno-ekonomiczna, 2) funkcja opiekuńczo-zabezpieczająca;

III. Funkcje społeczno-wyznaczające: 1) funkcja stratyfikacyjna, 2) funkcja legalizacyjno-kontrolna;

IV. Funkcje socjopsychologiczne: 1) funkcja socjalizacyjno-wychowawcza, 2) funkcja kulturalna, 3) funkcja religijna, 4) funkcja rekreacyjno-towarzyska, 4) funkcja emocjonalno-ekspresyjna ${ }^{15}$.

Właściwie funkcjonująca rodzina wskazuje drogę ku społeczeństwu i ułatwia pokonywanie progów coraz szerszych kręgów środowiskowych. Taka rodzina sprzyja poznaniu przez młode pokolenie

Por. J. Pięta, Pedagogika czasu wolnego, Warszawa 2004, s. 216. Tamże, s. 223.

14 Por. Z. Tyszka, Rodzina, w: Encyklopedia pedagogiczna, red. W. Pomykało, Warszawa 1993, s. 695.

15 Tamże, s. 698. 
fundamentów rodzinnej i narodowej kultury. Ważne jest równocześnie i to, że w prawidłowo działającej rodzinie człowiek ma szansę doświadczać wartości dla siebie i świata, podejmować trud autokreacji, a także w odpowiednich momentach życia uzyskać konieczne wsparcie $^{16}$.

Jednak jak wskazują wyniki badań, w obecnych czasach rodzina w coraz mniejszym stopniu pełni funkcję kulturotwórczą. Przekaz kultury dociera do młodego pokolenia $\mathrm{z}$ wielu źródeł (media, grupy rówieśnicze, szkoła), a ich treść stoi często w opozycji do tego, co proponuje rodzina. Rodzina staje się coraz bardziej zlepkiem indywidualności dążących do niezależnego realizowania swoich potrzeb i celów niż grupą, którą łączą jakieś wspólne ideały i działania ${ }^{17}$.

Rodzina jednak, w swoim zintegrowanym uniwersalizmie społecznego i psychospołecznego funkcjonowania, jest jak dotychczas nie do zastąpienia i nie sposób sobie wyobrazić jej nieobecności w społeczeństwie lub katastrofalnych efektów jej krańcowej patologizacji, gdyby takowa miała nastąpić w okresie dalszego rozwoju cywilizacji postindustrialnej. Ludzkość nie wypracowała dotychczas innej instytucji, która mogłaby skutecznie zastąpić rodzinę i nie wiadomo, czy uda się to w przyszłości ${ }^{18}$.

Zdaniem Z. Żukowskiej rodzina przechodzi w ostatnich latach znaczącą ewolucję. Dotyczy to w szczególności warunków interakcji rodzice - dzieci. Partnerstwo w tej interakcji, podmiotowe a nie przedmiotowe traktowanie dziecka $\mathrm{w}$ rodzinie, stosunki oparte na szacunku i wzajemnej życzliwości, pozbawione rygoryzmu i przymusu, przepełnione miłością, są szansą na wspólne uczestnictwo w kulturze fizycznej rodziny i są doskonałym sposobem zacieśniania więzi rodzinnych ${ }^{19}$.

16 Por. A.W. Janke, Wolnościowy aspekt wychowania w rodzinie w perspektywie interakcjonizmu symbolicznego, w: Wolność jako wartość i problem edukacyjny, red. A.M. de Tchorzewski, Bydgoszcz 1999, s. 124.

17 Por. T. Biernat, P. Sobierajski, Mtodzież wobec matżeństwa i rodziny. Raport z badań, Toruń 2007, s. 13.

18 Por. Z. Tyszka, Rodzina w świecie wspótczesnym - jej znaczenie dla jednostki i spoteczeństwa, w: Pedagogika spoteczna. Cztowiek w zmieniającym się świecie, red. T. Pilch, I. Lepalczyk, Warszawa 2003, s. 152.

19 Por. Z. Żukowska, Kultura fizyczna a rodzina, w: Kultura fizyczna a rodzina. Materiaty z ogólnopolskiej konferencji naukowo-metodycznej zorganizowanej 


\section{Wychowawczy potencjał czasu wolnego, rekreacji i turystyki}

Każde zachowanie w czasie wolnym może mieć charakter czynny lub bierny, mniej lub bardziej świadomy, a w zależności od formy może być zachowaniem receptywnym, kreatywnym, konsumpcyjnym, odtwórczym, zabawowym lub kontemplacyjnym ${ }^{20}$.

M. Czerepaniak-Walczak dostrzega potrzebę włączenia refleksji nad wychowawczą mocą czasu wolnego w problematykę wychowania. Stwierdza bowiem, że prawa człowieka i prawa dziecka do czasu wolnego wywołują konieczność wypracowania wychowawczych sposobów respektowania tego prawa, zarówno w wymiarze podmiotowym, jak i przedmiotowym, tzn. formalnej jego organizacji ${ }^{21}$.

Zdaniem J. Pięty działalność pedagogiczna w zakresie czasu wolnego powinna być ukierunkowana na realizację dwóch rodzajów ogólnych zadań: 1) profilaktycznych, 2) kreacyjnych. Dzięki realizacji zadań pierwszego rodzaju następowałoby eliminowanie i minimalizowanie wysoce niekorzystnych zjawisk w obrębie czasu wolnego, natomiast realizacja zadań drugiego rodzaju dostarczałaby inspiracji i zaprawiałaby do twórczych poszukiwań wzorów zachowań wolnoczasowych, zdobywania większego mistrzostwa, osiągania wyższych sprawności i realizacji wartości wyższego rzędu ${ }^{22}$.

Zajmując się czasem wolnym dzieci i młodzieży należy koniecznie uwzględnić jego specyficzną cechę, różniącą go od czasu wolnego człowieka dorosłego. Podlega on bowiem kontroli i ingerencji rodziców, wychowawców szkolnych, instytucji w których młodzież przebywa. Ogólnie można stwierdzić, że za zajęciami czasu wolnego dzieci i młodzieży kryje się wpływ wychowawczy dorosłych ${ }^{23}$.

11-12.11.1994 r. w Biatej Podlaskiej, red. S. Arasymowicz, Biała Podlaska 1996, s. 6-8.

20 Por. R. Winiarski, Wstęp do teorii rekreacji (ze szczególnym uwzględnieniem rekreacji fizycznej), dz. cyt., s. 80.

21 Por. M. Czerepaniak-Walczak, Wychowanie do czasu wolnego: poszukiwanie miejsca dla homo ludens w świecie homo faber, w: Wychowanie. Pojęcia - Procesy-Konteksty, red. M. Dudzikowa, M. Czerepaniak-Walczak, Gdańsk 2007, s. 304-305.

22 Por. J. Pięta, Pedagogika czasu wolnego, dz. cyt., s. 184-187.

23 Por. A. Łukawska, Nauka i czas wolny uczniów szkól podstawowych i średnich, Kraków 1991, s. 164. 
Analizując aspekty czasu wolnego w stosunku do dzieci i młodzieży możemy za M. Kwilecką przyjąć, że: 1) w aspekcie socjologiczno-ekonomicznym czas wolny ułatwia kontakty i przeżycia społeczne, 2) w aspekcie psychologiczno-pedagogicznym ma wartość dostarczania informacji - dostarcza nowych wrażeń, pozwala na odkrywanie i rozbudzanie zainteresowań nowymi zjawiskami i obiektami, 3) w aspekcie higieniczno-zdrowotnym czas wolny jest niezbędny jako zabezpieczanie młodego organizmu przed nadmiernym obciążeniem obowiązkami i zadaniami szkolnymi, spełnia profilaktyczną rolę ochrony zdrowia dzieci i młodzież $\mathrm{y}^{24}$.

Pedagogiczna wartość czasu wolnego w stosunku do dzieci i młodzieży polega na tym, że stwarza on sytuacje, w których muszą przejawiać inicjatywę, aktywność i umiejętności organizowania sobie zajęć wykraczających poza program ich codziennych obowiązków (szkoła, dom), a występujących jako odrębne wolne momenty dnia, z którymi trzeba coś zrobić. W czasie wolnym dzieci i młodzież mają zatem okazję do przejawiania własnej inicjatywy i samodzielności. Jednym z dodatnich elementów pedagogicznych aspektów czasu wolonego jest dochodzenie przez samo dziecko do zrozumienia konieczności samowychowania, stałego podnoszenia swoich umiejętności oraz ich doskonalenia ${ }^{25}$.

$\mathrm{Z}$ punktu widzenia rozważań niniejszego artykułu najodpowiedniejszą definicją czasu wolnego wydaje się ta zaproponowana przez W. Siwińskiego. Stwierdził on, że pozaszkolna kultura fizyczna i turystyka zajmując się problematyką wolnego czasu człowieka definiuje go jako czas, który pozostaje jednostce po zaspokojeniu elementarnych potrzeb organizmu, wypełnieniu obowiązków domowych, rodzinnych i zarobkowych, jako czas, w którym może ona zachowywać się i wykonywać czynności sportowo-rekreacyjno-turystyczne według swego upodobania, podejmować je dobrowolnie dla odpoczynku, przyjemności, w celu rozwoju własnej osobowości lub poświęcać się działalności społecznej w stowarzyszeniach i organizacjach kultury fizycznej i turystyki ${ }^{26}$.

Por. M. Kwilecka, Bezpośrednie funkcje rekreacji, Warszawa 2006, s. 77-80.

Por. K. Czajkowski, Wychowanie do rekreacji, Warszawa 1979, s. 52.

Por. W. Siwiński, Wspótczesne problemy turystyki i rekreacji w badaniach empirycznych nauk spotecznych, Warszawa 2007, s. 216. 
Dla potrzeb teorii i praktyki wychowania niezbędna jest klasyfikacja poszczególnych rodzajów aktywności proponowanych dzieciom i młodzieży w czasie wolnym. Są nimi:

- rekreacja ruchowa i sport,

- turystyka aktywna i poznawcza,

- czynne uczestnictwo w imprezach artystycznych oraz amatorstwo artystyczne,

- recepcja środków masowej komunikacji (czytelnictwo, film, radio, telewizja, Internet),

- wszelkie formy aktywności intelektualnej, zajęcia techniczne, warsztatowe i konstrukcyjne,

- aktywność społeczna i towarzyska (między innymi w grupach rówieśniczych),

- inne formy aktywności (kolekcjonerstwo, różnego rodzaju indywidualne zamiłowania w tym dotyczące aktywności ruchowej ${ }^{27}$.

Z powyższego wynika, że jednymi z najbardziej pożądanych form realizacji czasu wolnego przez dzieci i młodzież są rekreacja ruchowa i turystyka (szczególnie turystyka aktywna).

Pojęcie rekreacji ruchowej, rozumiane jest w niniejszej pracy jako wszystkie zajęcia (czynności) ruchowe, którym człowiek oddaje się z własnej chęci w czasie wolnym dla odpoczynku, rozrywki, pomnażania zdrowia i samodoskonalenia - społecznie aprobowane ${ }^{28}$.

Natomiast biorąc pod uwagę aspekty dydaktyczno-wychowawcze, pod pojęciem turystyki będziemy rozumieć każdy czasowy wyjazd poza miejsce stałego zamieszkania, którego celem i efektem jest wpływ na zmiany w szeroko rozumianym pojęciu osobowości. Zmiany te mogą dotyczyć zarówno sfery intelektualnej (przyrost wiedzy), emocjonalnej (poczucie odprężenia) oraz działaniowej (nawiązywanie nowych kontaktów społecznych) ${ }^{29}$.

Z badań pedagogiki kultury fizycznej wynika, że uczestnictwo $\mathrm{w}$ rekreacji i turystyce nie tylko zaspokaja potrzeby poznawcze

27 Por. M. Kwilecka, Bezpośrednie funkcje rekreacji, dz. cyt., s. 47.

T. Wolańska, Leksykon. Sport dla wszystkich - rekreacja ruchowa, dz. cyt., s. 22.

29 Por. K. Lubański, Pedagogiczny potencjat turystyki, „Zeszyty Naukowe ALMAMER” 2006, nr 3, s. 150. 
i emocjonalne jednostki ludzkiej, ale także oddziałuje wychowawczo, rozwija różnorodne potrzeby i sposoby ich zaspokajania ${ }^{30}$.

Jak wskazują w swoich licznych pracach znawcy tematu (K. Denek, K. Przecławski, T. Łobożewicz i inni) aktywność turystyczna: 1) może być środkiem poznania rzeczywistości; 2) może kształtować określone postawy wobec rzeczywistości; 3) może być środkiem kształtowania uczuć; 4) stwarza możliwość działania twórczego; 5) przyczynia się do potęgowania zdrowia; 6) może być czynnikiem resocjalizacji ${ }^{31}$.

\section{Wychowanie do czasu wolnego, rekreacji i turystyki}

Ciągle postępujący wzrost ilości czasu wolnego niesie za sobą potrzebę wychowania społeczeństwa do umiejętnego, pożytecznego, wartościowego, zdrowego, moralnego i kulturalnego jego zagospodarowania i tym samym dążenia do uzyskiwania wyższej jakości życia. Jest to konieczne dlatego, aby ludzie właściwie potrafili rozwinąć zrównoważony i zróżnicowany wachlarz zachowań, poprzez kreowanie pożądanych postaw, zainteresowań, motywacji, zwyczajów i umiejętności całego życia ${ }^{32}$. Sens bowiem życia członków społeczeństwa nowoczesnego sprowadza się do organizowania swojego czasu wolnego ${ }^{33}$. Gospodarowanie czasem wolnym to nic innego jak wykorzystywanie go w celu przekształcenia siebie i warunków swego życia zgodnie ze swymi planami, potrzebami i aspiracjami ${ }^{34}$.

Tak więc wychowanie do czasu wolnego to zamierzone i celowe działanie wychowawców i środowiska społecznego ukierunkowane na wywołanie trwałych zmian w osobowości wychowanka, przejawiających się rozbudzeniem zainteresowania różnymi formami

30 Por. W. Siwiński, Wspótczesne problemy turystyki i rekreacji w badaniach empirycznych nauk spotecznych, dz. cyt., s. 115.

31 Por. K. Przecławski, Socjologiczne problemy turystyki, Warszawa 1979, s. 98-99.

32 Por. T. Łobożewicz, G. Bieńczyk, Podstawy turystyki, Warszawa 2001, s. 38.

33 Por. M. Kwilecka, Bezpośrednie funkcje rekreacji, dz. cyt., s. 68.

34 Por. Po pracy i nauce. Wzory zachowań mtodzieży w czasie wolnym, red. K. Przecławski, Warszawa 1979, s. 7. 
wczasowania oraz internalizacji określonych potrzeb, wartości, motywacji i postaw związanych z racjonalnym spędzaniem czasu wolnego ${ }^{35}$.

Celem wychowania w czasie wolnym powinno być także przygotowanie człowieka do spędzania czasu wolnego indywidualnie oraz w grupach niezinstytucjonalizowanych. Ludzie mogą bowiem osiągać pełnię swojego rozwoju w okresie czasu wolnego wtedy, kiedy są wprowadzani w możliwość samodzielnego decydowania o sposobie jego wykorzystania ${ }^{36}$.

Natomiast przez wychowanie do rekreacji należy rozumieć działanie intencjonalne mające na celu przygotowanie człowieka do aktywnego spędzania czasu wolnego w zakresie uczestnictwa w ruchu kulturalno-sportowym i turystycznym ${ }^{37}$.

Edukacja do rekreacji przebiega dwutorowo: w drodze bezpośredniej edukacji jednostek (rodzina i szkoła) oraz ma charakter bezosobowy poprzez środki masowego przekazu. Edukacja w zakresie rekreacji może być realizowana $\mathrm{z}$ uwzględnieniem następujących zasad:

- permanentnego kształtowania świadomości, potrzeb i nawyków jednostki dotyczących właściwego wykorzystania czasu wolnego;

- integrowania działalności wychowawczej związanej z aktywnością rekreacyjną poprzez wszystkie kręgi oddziaływania, tj. rodzinę, szkołę, organizacje społeczne, zakłady pracy, ośrodki wypoczynkowe i środki masowego przekazu ${ }^{38}$.

Bardzo ważne w tym kontekście jest również wykorzystanie wychowawczych wartości turystyki, która według przedstawionych już w tym artykule rozważań, stanowi jeden z najbardziej pożądanych sposobów realizacji czasu wolnego. W tym miejscu warto przedstawić

Por. W. Siwiński, Pedagogika czasu wolnego i jej zwiqzki z rekreacja, w: Teoria $i$ metodyka rekreacji. Zagadnienia podstawowe, red. I. Kiełbasiewicz-Drozdowska, W. Siwiński, Poznań 2001, s. 29.

38 Por. W. Siwiński, Wspótczesne problemy turystyki i rekreacji w badaniach empirycznych nauk spotecznych, dz. cyt., s. 30-31. 
koncepcję K. Lubańskiego, który wyróżnił trzy etapy realizacji procesu wykorzystania turystyki dla potrzeb wychowania ${ }^{39}$ :

- Etap I-Wychowanie przez turystykę.

Uczestnictwo dzieci i młodzieży w imprezach turystycznych organizowanych przez przedszkole, szkołę, rodzinę, czy różnego rodzaju organizacje społeczne. Jego głównym zadaniem powinno być kształtowanie doświadczeń turystycznych, które będą w dużym stopniu decydowały o przyszłej aktywności jednostki w tym zakresie.

- Etap II - Wychowanie do turystyki.

Może być traktowany jako jeden z celów wychowania przez turystykę. Jego istotą jest wyrobienie przeświadczenia o korzyściach, jakie niesie ze sobą jej uprawianie i ma w założeniu doprowadzić do podjęcia przez jednostkę decyzji o podjęciu samodzielnej aktywności turystycznej, dlatego tak ważne jest ukazanie jej wielostronności, sprzyjającej odpowiedniemu wyborowi form.

Czyli, jak podkreśla W. Siwiński, wychowanie przez turystykę i do turystyki to „ciągłe (permanentne) przygotowanie jednostki do aktywnego, samodzielnego i racjonalnego wypełniania czasu wolnego, do różnorakiej działalności turystyczno-rekreacyjnej aprobowanej społecznie, dającej wypoczynek kulturalno-sportowy i rozrywkę, rozwijające osobowość" 40 oraz nabywanie społecznie pożądanych cech charakteru i osobowości takich, jak: zaradność, umiejętność współpracy w grupie, odpowiedzialność za siebie i innych. Współcześnie praktyczną stronę wychowania do turystyki wyznacza nam kształcenie turystyczne - edukacja turystyczna w zakresie technik turystycznych, wiedzy i umiejętności niezbędnych do uprawiania różnych rodzajów, dyscyplin oraz form turystyki ${ }^{41}$.

Por. K. Lubański, Pedagogiczny potencjat turystyki, dz. cyt., s. 159.

Por. E. Mucha-Szajek, Turystyka jako przedmiot badań nauk spotecznych kultury fizycznej, w: Wspótczesne problemy hotelarstwa, gastronomii, turystyki i rekreacji, red.W. Siwiński, R.D. Tauber, E. Mucha-Szajek, Poznań 2008, s. 45. Por. A. Dąbrowski, R. Rowiński, Wptyw szkoty na ksztattowanie potrzeb turystycznych uczniów, w: Aksjologia turystyki, red. Z. Dziubiński, Warszawa 2006, s. 90. 
- Etap III - Samowychowanie przez turystykę.

Jest to etap poprzedzony uświadomieniem sobie korzyści płynących z uprawiania turystyki i jej kreatywnej roli dla rozwoju osobowości, w czym ogromną rolę spełnia autopsja. Istotą tego etapu procesu wychowania turystycznego jest świadomie dokonany wybór takiej formy spędzania czasu wolnego oraz świadome wykorzystanie jej dla samodzielnego kierowania własnym rozwojem.

Jednak jak podkreśla W. Siwiński, samowychowanie do rekreacji i turystyki jest zawsze następstwem wcześniejszych wpływów zewnętrznych i z tego względu ma charakter wtórny. Jednostka stawia sobie te cele i zadania wobec rekreacji i turystyki oraz stosuje takie metody pracy nad sobą i kryteria oceny siebie, które jej wcześniej przyswojono ${ }^{42}$.

Możemy zauważyć, że edukacja turystyczna powinna stać się elementem składowym i formą procesu wychowania do czasu wolnego.

Zdaniem K. Przecławskiego, siła oddziaływania wychowawczego turystyki będzie tym większa, im wcześniej ono się rozpocznie, im we wcześniejszym okresie życia młodego człowieka ktoś go „wprowadzi” w turystykę, ktoś go nauczy jej uprawiania. Jest to zadanie zarówno rodziny, jak też szkoły, organizacji młodzieżowych, społecznych, wyspecjalizowanych biur turystycznych i zakładu pracy. Jest także zadaniem placówek wychowania pozaszkolnego oraz środków masowego przekazu $^{43}$.

42 Por. W. Siwiński, Wspótczesne problemy turystyki i rekreacji w badaniach empirycznych nauk spotecznych, dz. cyt., s. 122.

43 Por. K. Przecławski, Turystyka a wychowanie, Warszawa 1973, s. 99. 
Tabela 1. Wychowanie do rekreacii (ogół wpływów)

\begin{tabular}{|c|c|c|}
\hline $\begin{array}{l}\text { Źródło wpływów, } \\
\text { emisor treści } \\
\text { wychowawczych } \\
\text { i socjalizacyinych }\end{array}$ & Przekaz (drogi, sposoby wpływu) & $\begin{array}{l}\text { Korzyści i efekty działań } \\
\text { socjalizujących i wychowawczych }\end{array}$ \\
\hline Rodzina & $\begin{array}{l}\text { - poprzez codzienne, intencjonalne dzia- } \\
\text { łania wychowawcze oraz nieplanowa- } \\
\text { ne działania socjalizujace } \\
\text { - poprzez działania przykładem oso- } \\
\text { bistym }\end{array}$ & $\begin{array}{l}\text { - silna internalizacja potrzeb i wartości } \\
\text { w zakresie aktywnego stylu życia, } \\
\text { - przyimowanie za własny wzor- } \\
\text { ców aktywnego spędzania czasu } \\
\text { wolnego, } \\
\text { - nabywanie nawyków aktywności } \\
\text { wolnoczasowej i rekreacyjnej, }\end{array}$ \\
\hline Szkoła & $\begin{array}{l}\text { - poprzez celowe działania: } \\
\text { - wychowawcze } \\
\text { - edukacyine (kształcenie) za pomoca } \\
\text { treści, środków i metod dydaktycz- } \\
\text { nych poprzez osobę nauczyciela - } \\
\text { wychowawcy }\end{array}$ & $\begin{array}{l}\text { - wykreowanie pewnego powszech- } \\
\text { nego poziomu wiedzy i świadomości } \\
\text { w zakresie konieczności aktywności } \\
\text { ruchowej i zdrowego stylu życia, } \\
\text { - propagowanie pozytywnych wzor- } \\
\text { ców spędzania czasu wolnego }\end{array}$ \\
\hline $\begin{array}{l}\text { Instytucje wspo- } \\
\text { magajace } \\
\text { (harcerstwo, } \\
\text { organizacje } \\
\text { młodzieżowe, } \\
\text { sportowe, itp.) }\end{array}$ & $\begin{array}{l}\text { - poprzez celowe działania: } \\
\text { - wychowawcze } \\
\text { - edukacyine } \\
\text { - poprzez osoby wychowawcy- } \\
\text { - animatora } \\
\text { - działanie metodami: } \\
\text { - wpływu osobistego } \\
\text { - wpływu sytuacyinego } \\
\text { - wpływu społecznego }\end{array}$ & $\begin{array}{l}\text { - tworzenie poziomu wiedzy i świa- } \\
\text { domości dotyczqcej zdrowego stylu } \\
\text { życia } \\
\text { - przedstawianie pozyływnych } \\
\text { wzorców i propozycii aktywności } \\
\text { rekreacyjnych }\end{array}$ \\
\hline $\begin{array}{l}\text { Grupy rówieś- } \\
\text { nicze }\end{array}$ & $\begin{array}{l}\text { - intencionalne i nieintencjonalne } \\
\text { - działania normo i opiniotwórcze } \\
\text { - działanie przykładem własnym } \\
\text { - silne procesy indentyfikacyine } \\
\text { w grupach }\end{array}$ & $\begin{array}{l}\text { - w przypadku „pozytywnie mo- } \\
\text { tywujacych” grup rówieśniczych } \\
\text { w zakresie aktywności wolnoczaso- } \\
\text { wej, przyimowanie i naśladownictwo } \\
\text { gotowych wzorów zachowań }\end{array}$ \\
\hline $\begin{array}{l}\text { Społeczność } \\
\text { lokalna }\end{array}$ & $\begin{array}{l}\text { - głównie niecelowe i nieintencjonal- } \\
\text { ne działania normo i opiniotwórcze } \\
\text { wywierajace presję na jednostkę } \\
\text { (potrzeba akceptacii, konformizmu) } \\
\text { - działania przykładem własnym - } \\
\text { naśladownictwo (jedność wzorców } \\
\text { społeczno-kulturowowych) }\end{array}$ & $\begin{array}{l}\text { - wytwarzanie nawyków i potrzeb } \\
\text { w zakresie aktywności ruchowej } \\
\text { adekwatnych do proponowanych } \\
\text { i akceptowanych przez społeczność } \\
\text { lokalna } \\
\text { - silna funkcja kontrolna zarówno } \\
\text { w zakresie pozytywnych jak i nega- } \\
\text { tywnych wzorów zachowań }\end{array}$ \\
\hline $\begin{array}{l}\text { Środki masowe- } \\
\text { go przekazu }\end{array}$ & $\begin{array}{l}\text { - elementy polityki państwa w zakresie } \\
\text { zdrowia publicznego } \\
\text { - celowe programy edukacyjne } \\
\text { - celowe działania indoktrynujqce } \\
\text { - celowe działania homogenizujace } \\
\text { wartości i wzory }\end{array}$ & $\begin{array}{l}\text { - wpływ zróżnicowany w różnych } \\
\text { grupach odbiorców } \\
\text { - powierzchowność przyjmowanych } \\
\text { wzorców } \\
\text { - silne działania czynnika mody } \\
\text { - duże znaczenie edukacyjne }\end{array}$ \\
\hline
\end{tabular}




\begin{tabular}{|c|c|c|}
\hline $\begin{array}{l}\text { Źródło wpływów, } \\
\text { emisor treści } \\
\text { wychowawczych } \\
\text { i socjalizacyinych }\end{array}$ & Przekaz (drogi, sposoby wpływu) & $\begin{array}{l}\text { Korzyści i efekty działań } \\
\text { socjalizujących i wychowawczych }\end{array}$ \\
\hline Kościół & $\begin{array}{l}\text { - intencionalne działania wychowawcze } \\
\text { - programy edukacyine } \\
\text { - działania metodami: } \\
\text { - wpływu osobistego } \\
\text { - wpływu sytuacyjnego } \\
\text { - wpływu społecznego }\end{array}$ & $\begin{array}{l}\text { - wytwarzanie określonego stanu } \\
\text { świadomości } \\
\text { - przedstawianie alternatywnych } \\
\text { sposobów zachowań rekreacyj- } \\
\text { nych } \\
\text { - silna funkcja kontrolna }\end{array}$ \\
\hline
\end{tabular}

Źródło: Teoria i metodyka rekreacji. Zagadnienia podstawowe, red. I. Kiełbasiewicz-Drozdowska, W. Siwiński, Poznań 2001, s. 48.

\section{Wpływ rodziny na aktywność rekreacyjnq i turystycznq w czasie wolnym}

Jak już wcześniej wspominano, dom rodzinny jest najważniejszym i pierwszym ogniwem wychowania młodego człowieka. Odgrywa on najistotniejszą rolę w kształtowaniu postaw i zainteresowań dzieci i młodzieży. Wpływa na wzory, nawyki i umiejętności organizowania czasu wolnego. To właśnie rodzice ponoszą szczególną odpowiedzialność za kształtowanie kultury wolnego czasu u swoich dzieci. Czas ten podlega bowiem rygorom wychowawczym, kontroli oraz częściowej ingerencji dorosłych. Istotne znaczenia ma więc umiejętne manipulowanie wzorami spędzania czasu wolnego w rodzinie ${ }^{44}$.

$\mathrm{Na}$ fakt ten zwrócił uwagę $\mathrm{Z}$. Tyszka, umieszczając wśród funkcji socjopsychologicznych rodziny funkcję rekreacyjno-towarzyską, czyli ukazującą wzory zachowań wolnoczasowych ${ }^{45}$.

W. Siwiński wymienia następujące zadania współczesnej rodziny związane $\mathrm{z}$ organizowaniem czasu wolnego dzieci, młodzieży oraz z podnoszeniem kultury spędzania czasu wolnego: 1) kształtowanie zainteresowań i zamiłowań dziecka; 2) udzielanie porad dziecku, jak należy czas wolny spędzać; 3) bezpośrednie organizowanie czasu wolnego na zajęciach sportowo-rekreacyjno-turystycznych, kierowanie

44 Por. M. Grochociński, Przygotowanie dzieci do racjonalnego wykorzystania czasu wolnego, Warszawa 1979, s. 34.

45 Por. Z. Tyszka, Rodzina, w: Encyklopedia pedagogiczna, red. W. Pomykało, dz. cyt., s. 698. 
dzieci do odpowiednich placówek wychowania pozaszkolnego, np. związanego z działalnością kultury fizycznej i turystyki; 4) roztoczenie opieki nad czasem wolnym dzieci spędzonym poza domem ${ }^{46}$.

T. Wolańska podkreśla również, że czas wolny i rekreacja odgrywają istotną rolę nie tylko w sporadycznych ,imprezach” rodzinnych, czy zaplanowanych zajęciach, ale także w zwyczajnym życiu rodziny, gdyż codzienność i wszelkie sprawy z nią związane stanowią istotę czasu wolnego, ogólnej atmosfery domu rodzinnego, zrozumienia, życzliwości komunikowania się. Stanowią także podstawę i motywy rozwijania różnych form życia i działania rodziny w dziedzinie czasu wolnego i rekreacji ${ }^{47}$.

K. Czajkowski apeluje, aby planowe wprowadzanie dziecka do uczestnictwa w wypoczynku ruchowo aktywnym rozpoczynało się już około trzeciego roku życia i powinno być kontynuowane przez rodziców jak najdłużej ${ }^{48}$. W kolejnych latach życia rola rodziców w wychowaniu do i przez rekreację, turystykę i sport może zostać ograniczona, ale jak zauważył T. Kowalik, nigdzie nie zostało to jednoznacznie stwierdzone, że powinno ustać ${ }^{49}$.

Możemy w tym miejscu za Z. Dziubińskim użyć pojęcia „procesu socjalizacji pierwotnej do kultury fizycznej”. Bowiem w tym okresie, w sposób niejako naturalny, w grupie pierwotnej jaką jest rodzina, przekazywane i jednocześnie zinternalizowane są idee, wzory, wartości i postawy względem kultury fizycznej. Tworzą się fundamenty osobowości człowieka w odniesieniu do kultury fizycznej ${ }^{50}$.

Ciekawego zestawienia wyników dotychczasowych badań nad rodziną jako środowiskiem wychowującym do aktywnego wypoczynku dokonała B. Maj. Na podstawie publikacji z lat 1978-1997

Por. W. Siwiński, Spoteczno-wychowawcze zadania specjalisty kultury fizycznej i turystyki w organizacji czasu wolnego dla osób w różnych grupach wiekowych, w: Turystyka, rekreacja i sport jako problem wychowawczy wspótczesnego cztowieka, red. W. Siwiński, Poznań 1993, s. 211.

47 Por. T. Wolańska, Rekreacja fizyczna i turystyka w rodzinie, w: Kultura fizyczna a rodzina. Materiaty z ogólnopolskiej konferencji naukowo-metodycznej zorganizowanej 11-12.11.1994 r. w Biatej Podlaskiej, red. S. Arasymowicz, Biała Podlaska, s. 20.

48 Por. K. Czajkowski, Wychowanie do rekreacji, dz. cyt., s. 101.

49 Por. T. Kowalik, Turystyka rodzinna, Warszawa 1982, s. 8.

50 Por. Z. Dziubiński, Socjalizacja do kultury fizycznej. Socjologiczna próba przybliżenia zagadnienia, „Lider” 2009, nr 12, s. 7-11. 
doszła ona do kilku ciekawych wniosków. Stwierdziła m.in., że tylko niewielka część rodzin (zwykle lepiej wykształconych) potrafiła właściwie ukierunkować dzieci i młodzież bądź zainicjować ciekawe i pożyteczne dla zdrowia pomysły wykorzystania czasu wolnego. Rodzice o niższym poziomie wykształcenia rzadko dostrzegali potrzebę wspólnego ze swymi pociechami planowania zajęć wypoczynkowych. Ponadto młody człowiek skłonny był do przejmowania od osób najbliższych wzorów wykorzystania godzin wolnych, wśród których wysoką pozycję zajmował wypoczynek bierny ${ }^{51}$.

Podobne stanowisko w tym względzie zajmują inni znawcy tematu, m.in. H. Piotrowska, która zaobserwowała dużą rozbieżność między zakładaną a realizowaną funkcją rodziny w wychowaniu do rekreacji fizycznej ${ }^{52}$.W. Siwiński na podstawie ogólnopolskich badań stwierdził, że około 90\% rodziców nie potrafi określić celów, metod i treści szkolnego wychowania fizycznego uznając, że to sprawa wewnętrzna szkoły ${ }^{53}$.

Funkcjonuje tu swego rodzaju „błędny łańcuch”, polegający na tym, że rodzice sami nie posiadając nawyków aktywnego i kreatywnego spędzania wolnego czasu, nie są $\mathrm{w}$ stanie wyrabiać ich u swoich dzieci. $Z$ kolei dzieci, stając się z biegiem czasu same rodzicami, kontynuują tę „bierną tradycję”, przekazując ją następnym pokoleniom ${ }^{54}$.

Jednak, na co zwraca uwagę J. Rut, niepodważalne jest stwierdzenie, że rola domu rodzinnego w wychowaniu do turystyki i rekreacji jest podstawowa i rodzina nie może być zastąpiona przez żadną inną placówkę ${ }^{55}$. Rolę tą dostrzega również S. Toczek-Werner, która apeluje, by program zjednywania ludzi do rekreacji w pierwszej kolejności obejmował rodzinę. Dzieci bowiem powinny z domu wynieść przyzwyczajenie do różnych rodzajów aktywnych form rekreacji i turystyki, pożytecznego spędzania czasu wolnego ${ }^{56}$.

51 Por. B. Maj, Spoteczne uwarunkowania rekreacji ruchowej i turystyki mtodzieży wielkomiejskiej, Kraków 2007, s. 31.

52 Por. H. Piotrowska, Teoretyczne podstawy rekreacji, w: „Sport dla wszystkich”. Rekreacja dla każdego, red. T. Wolańska, Warszawa 1994, s. 15.

53 Por. W. Siwiński, Wspótczesne problemy turystyki i rekreacji w badaniach empirycznych nauk spotecznych, dz. cyt., s. 181.

54 Por. R. Winiarski, Wstęp do teorii rekreacji (ze szczególnym uwzględnieniem rekreacji fizycznej), dz. cyt., s. 127.

55 Por. J. Rut, Turystyka i rekreacja dla pracy i wypoczynku, Rzeszów 1998, s. 55.

56 Por. Podstawy turystyki, red. S. Toczek-Werner, Wrocław 2005, s. 25. 
Zdaniem K. Przecławskiego, to właśnie rodzina powinna zacząć kształtować postawę poznawczo-obserwatorską, uczyć dostrzegać piękno przyrody, uwrażliwiać na dzieła rąk ludzkich, zainteresować życiem innych ludzi, kształtować postawę aktywną. Działalność rodziny w tym zakresie powinna przejawiać się w: przygotowywaniu dzieci do uprawiania turystyki poprzez kupowanie odpowiednich książek, map, przewodników; wspólnych rodzinnych spacerach; poprzez tzw. małą turystykę codzienną (np. wycieczki weekendowe, ale również popołudniowe wypady z dzieckiem na narty, rower); spacery po mieście (do muzeum, na wystawę itp.); wspólne przygotowywanie wraz z dziećmi wycieczek weekendowych oraz wyjazdów wakacyjnych (program, nocleg, wyżywienie) ${ }^{57}$.

Wyjazdy wycieczkowe, wędrówki turystyczne i wspólne pobyty w atmosferze niecodzienności, przygody i odprężenia korygować mogą chwilowo osłabione więzi rodzinne wywołane nadmiarem obowiązków, nerwowością bytu w życiu codziennym. Bliski, wzajemny kontakt poszczególnych członków rodziny, realizacja wspólnie nakreślonych planów i zamierzeń w trudnych niejednokrotnie warunkach wędrówki lub pobytu w terenie naturalnym sprzyjają tworzeniu silnych więzi rodzinnych ${ }^{58}$. Ponadto ukazują dzieci rodzicom, a także rodziców dzieciom w nieco innym świetle, w oderwaniu od codzienności życia, w nieco innej społecznej roli. Dzieci mogą wykazać się pewnymi umiejętnościami, jak zachowują się w sytuacjach różnych od sytuacji domowej lub obowiązków szkolnych ${ }^{59}$.

Wydaje się więc zasadne stwierdzenie, że wspólna aktywność turystyczna może przyczyniać się do integracji życia rodzinnego, a samo wychowanie przez turystykę będzie tym skuteczniejsze, im rodzice będą wcześniej przekonani i uznają jej codzienną przydatność, im wcześniej i systematyczniej będą stosować zasadę „turystyka uczy, bawi i wychowuje" ${ }^{\prime 0}$.

Por. K. Przecławski, Turystyka a wychowanie, dz. cyt., s. 99-102.

Por. T. Łobożewicz, T. Wolańska, Rekreacja i turystyka w rodzinie, Warszawa 1994, s. 50.

Por. K. Przecławski, Turystyka a wychowanie, dz. cyt., s. 101-102.

Por. T. Kowalik, Turystyka rodzinna, dz. cyt., s. 54. 


\section{Zakończenie}

Uczestnictwo w kulturze fizycznej i aktywność turystyczna nie są tylko sprawą swobodnego wyboru jednostki, ale ich poziom zdeterminowany jest kompleksem czynników, wśród których Z. Drozdowski wymienił najistotniejsze: wiek, dyspozycje somatyczno-motoryczne, stan zdrowia, a zwłaszcza motywacje. Te ostanie kształtowane są przede wszystkim w pierwotnym środowisku wychowawczym tj. rodzinie, której znaczenie w sferze wychowania do uczestnictwa w kulturze fizycznej trudno przecenić ${ }^{61}$. Obowiązek wychowania do kultury fizycznej (w tym do czasu wolnego, turystyki i rekreacji) polegający na popularyzowaniu wzorów, tworzeniu różnorakich modeli organizowania czasu wolnego, kształtowaniu nawyków, przyzwyczajeń i postaw ciąży również na szkole, organizacjach społecznych i środkach masowego przekazu ${ }^{62}$.

Proces ten, rozpoczynający się w dzieciństwie i trwający przez całe życie człowieka, zdaniem K. Czajkowskiego obejmuje:

1. rozbudzenie zainteresowań i potrzeb rekreacyjnych,

2. wzmacnianie motywacji oraz kształtowanie systemu wartości i postaw do rekreacji,

3. wyrabianie nawyków i umiejętności ruchowych,

4. zapoznanie $z$ nowymi formami rekreacji ${ }^{6}$.

Bardzo ważną rolę spełniają tu pozaszkolne formy kultury fizycznej, które poprzez swoją dobrowolność uczestnictwa, zawierają w sobie idee propozycji, pewnej oferty, a nie przymusu. Klimat swobodnego uczestnictwa, możliwość wyboru, stanowi istotny czynnik kształtowania stylu życia, przyspiesza i korzystnie kształtuje proces osobowościowego i społecznego dojrzewania ${ }^{64}$.

Umiejętne przeplatanie aktywnego trybu życia rodziny z propozycjami, jakie wysuną w tym zakresie szkoła i organizacje społeczne,

${ }^{61}$ Por. W. Siwiński, Wspótczesne problemy turystyki i rekreacji w badaniach empirycznych nauk spotecznych, dz. cyt., s. 181.

62 Por. M. Demel, W. Humen, Rola szkoty w wychorwaniu do rekreacji fizycznej, Warszawa 1970, s. 315.

63 Por. A. Dąbrowski, R. Rowiński, Wptyw szkoty na ksztattowanie potrzeb turystycznych uczniów, dz. cyt., s. 89.

64 Por. A. Dąbrowski, Pozaszkolna kultura fizyczna mtodzieży - rzeczywistość a potrzeby i oczekiwania, dz. cyt., s. 340. 
warunkować będzie utrwalenie nawyków i upodobań do aktywnego spędzania czasu wolnego oraz rozwój zainteresowań turystyką i krajoznawstwem u dzieci i młodzieży ${ }^{65}$. Efekty wychowania bowiem bardzo często są odległe w czasie. Tym samym doświadczenia turystyczne i rekreacyjne młodego człowieka uzyskane poprzez ofertę szkoły, rodziny i innych instytucji - będą przez niego docenione dopiero w dorosłym życiu. Doświadczenia te stanowią bardzo ważny wskaźnik skuteczności wychowania i kształcenia oraz przygotowania ucznia do funkcjonowania $\mathrm{w}$ społeczeństwie $\mathrm{w}$ charakterze pełnowartościowego członka ${ }^{66}$.

\section{Bibliografia}

Biernat T., Sobierajski P., Mtodzież wobec matżenstwa i rodziny. Raport z badań, Wydawnictwo Uniwersytetu Mikołaja Kopernika, Torun 2007.

Czajkowski K., Wychowanie do rekreacji, Wydawnictwa Szkolne i Pedagogiczne, Warszawa 1979.

Czerepaniak-Walczak M., Wychowanie do czasu wolnego: poszukiwanie miejsca dla homo ludens w świecie homo faber, w: Wychowanie. Pojęcia - Procesy - Konteksty, red. M. Dudzikowa, M. Czerepaniak-Walczak, GWP, Gdańsk 2007, s. 303-323.

Czerepaniak-Walczak M., Pedagogika czasu wolnego: schole w szkole i poza szkota, w: Rekreacja i czas wolny. Studia humanistyczne, red. R. Winiarski, Oficyna Wydawnicza Łośgraf, Warszawa 2011, s. 200-235.

Dąbrowski A., Pozaszkolna kultura fizyczna mtodzieży - rzeczywistośc a potrzeby i oczekiwania, Studia i Monografie, AWF, Warszawa 1997.

Dąbrowski A., Rowiński R., Wptyw szkoty na ksztattowanie potrzeb turystycznych uczniów, w: Aksjologia turystyki, red. Z. Dziubiński, Salezjańska Organizacja Sportowa RP, Warszawa 2006, s. 282-294.

Demel M., Humen W., Rola szkoty w wychowaniu do rekreacji fizycznej, „Studia Pedagogiczne"1970, nr 20, s. 315-317.

Dziubiński Z., Socjalizacja do kultury fizycznej. Socjologiczna próba przybliżenia zagadnienia, „Lider” 2009, nr 12, s. 7-11.

Grochociński M., Przygotowanie dzieci do racjonalnego wykorzystania czasu wolnego, WSiP, Warszawa 1979.

65 Por. T. Kowalik, Turystyka rodzinna, dz. cyt., s. 8.

66 Por. E. Mucha-Szajek, Turystyka jako przedmiot badań nauk spotecznych kultury fizycznej, dz. cyt., s. 49. 
Janke A.W., Wolnościowy aspekt wychowania w rodzinie w perspektywie interakcjonizmu symbolicznego, w: Wolnośc jako wartośc i problem edukacyjny, red. A.M. de Tchorzewski, Wydawnictwo „Wers”, Bydgoszcz 1999, s. $123-134$.

Kiełbasiewicz-Drozdowska I., Osobowościowe i spoteczne uwarunkowania rekreacji, w: Teoria $i$ metodyka rekreacji. Zagadnienia podstawowe, red. I. Kiełbasiewicz-Drozdowska, W. Siwiński, AWF, Poznań 2001, s. 4155.

Kosiewicz J., Czas wolny i wolność wyboru, w: Turystyka i rekreacja. Wymiary teoretyczne i praktyczne, red. J. Kosiewicz, K. Obodyński K., Wydawnictwo Naukowe Uniwersytetu Rzeszowskiego, Rzeszów 2006, s. 211-218.

Kowalik T., Turystyka rodzinna, Instytut Wydawniczy Związków Zawodowych, Warszawa 1982.

Kunowski S., Podstawy wspótczesnej pedagogiki, Wydawnictwo Salezjańskie, Warszawa 1996.

Kwilecka M., Bezpośrednie funkcje rekreacji, Almamer, Wyższa Szkoła Ekonomiczna, Warszawa 2006.

Lubański K., Pedagogiczny potencjat turystyki, „Zeszyty Naukowe ALMAMER” 2006, nr 3, s. 145-160.

Łobożewicz T., Wolańska T., Rekreacja i turystyka w rodzinie, PTNKF, Estella, Warszawa 1994.

Łobożewicz T., Bieńczyk G., Podstawy turystyki, Wyższa Szkoła Ekonomiczna, Warszawa 2001.

Eukawska A., Nauka i czas wolny uczniów szkót podstawowych i srednich, „Zeszyty Naukowe Uniwersytetu Jagiellońskiego”, Prace Pedagogiczne, 1991, z. 13, s. 131-158.

Maj B., Spoteczne uwarunkowania rekreacji ruchowej i turystyki mtodzieży wielkomiejskiej, Oficyna Wydawnicza Impuls, Kraków 2007.

Mucha-Szajek E., Turystyka jako przedmiot badań nauk spotecznych kultury fizycznej, Wspótczesne problemy hotelarstwa, gastronomii, turystyki i rekreacji, „Zeszyty Naukowe WSHiG” 2008, nr 3, s. 41-53.

Ożdziński J., Nowa rola czasu wolnego i rekreacji w Europie $i$ w Polsce, w: Rekreacja, turystyka, kultura, red. B. Marciszewska, J. Ożdziński, AWFiS, Gdańsk 2004, s. 11-24.

Pięta J., Pedagogika czasu wolnego, Wyższa Szkoła Ekonomiczna, Warszawa 2004.

Piotrowska H., Teoretyczne podstawy rekreacji, w: "Sport dla wszystkich”. Rekreacja dla każdego, red. T. Wolańska, TKKF Zarząd Główny, Warszawa 1994, s. 9-20.

Podstawy turystyki, red. S. Toczek-Werner, AWF, Wrocław 2005.

Po pracy i nauce. Wzory zachowań mtodzieży w czasie wolnym, red. K. Przecławski, Instytut Wydawniczy CRZZ, Warszawa 1979.

Przecławski K., Turystyka a wychowanie, Nasza Księgarnia, Warszawa 1973. 
Przecławski K., Socjologiczne problemy turystyki, Instytut Wydawniczy CRZZ, Warszawa 1979.

Przecławski K., Czas wolny dzieci i mtodzieży, w: Encyklopedia pedagogiczna, red. W. Pomykało, Fundacja Innowacja, Warszawa 1993, s. 75-76.

Rut J., Turystyka i rekreacja dla pracy $i$ wypoczynku, Wydawnictwo Koraw, Rzeszów 1998.

Siwiński W., Spoteczno-wychowawcze zadania specjalisty kultury fizycznej i turystyki w organizacji czasu wolnego dla osób w różnych grupach wiekowych, w: Turystyka, rekreacja i sport jako problem wychowawczy wspótczesnego cztowieka, red. W. Siwiński, PDW „£awica”, Poznań 1993, s. 210-214.

Siwiński W., Pedagogika czasu wolnego i jej zwiqzki z rekreacja, w: Teoria $i$ metodyka rekreacji. Zagadnienia podstawowe, red. I. Kiełbasiewicz-Drozdowska, W. Siwiński, AWF, Poznań 2001, s. 29-40.

Siwiński W., Wspótczesne problemy turystyki i rekreacji w badaniach empirycznych nauk spotecznych, Almamer, Warszawa 2007.

Szczepański J., Środowisko wychowawcze, w: Encyklopedia pedagogiczna, red. W. Pomykało, Fundacja Innowacja, Warszawa 1993, s. 819-820.

Toczek-Werner S., Czas wolny ucznia - nowe wyzwanie dla dziatalności edukacyjnej w szkole, w: Edukacja jutra. XIII Tatrzańskie Seminarium Naukowe, red. K. Zatoń, T. Koszyc, M. Sołtysik, Wrocław 2007, s. 285-294.

Tyszka Z., Rodzina, w: Encyklopedia pedagogiczna, red. W. Pomykało, Fundacja Innowacja, Warszawa 1993, s. 695-698.

Tyszka Z., Rodzina w śrwiecie wspótczesnym - jej znaczenie dla jednostki i spoteczeństwa, w: Pedagogika spoteczna. Cztowiek w zmieniajacym się świecie, red. T. Pilch, I. Lepalczyk, Wydawnictwo Akademickie „Żak”, Warszawa 2003, s. 137-154.

Wartecka-Ważyńska A., Turystyka mtodzieży i jej uwarunkowania, Wydawnictwo Naukowe UAM, Poznań 2007.

Winiarski R., Wstęp do teorii rekreacji (ze szczególnym uwzględnieniem rekreacji fizycznej), AWF, Kraków 1989.

Wolańska T., Rekreacja fizyczna i turystyka w rodzinie, w: Kultura fizyczna a rodzina. Materiaty z ogólnopolskiej konferencji naukowo-metodycznej zorganizowanej 11-12.11.1994 r. w Biatej Podlaskiej, red. S. Arasymowicz, PTNKF AWF w Warszawie, IWFiS w Białej Podlaskiej, Biała Podlaska 1996, s. 19-25.

Wolańska T., Leksykon. Sport dla wszystkich - rekreacja ruchowa, AWF, Warszawa 1997.

Żukowska Z., Kultura fizyczna a rodzina, w: Kultura fizyczna a rodzina. Materiaty z ogólnopolskiej konferencji naukowo-metodycznej zorganizowanej 11-12.11.1994 r. w Biatej Podlaskiej, red. S. Arasymowicz, PTNKF AWF w Warszawie, IWFiS w Białej Podlaskiej, Biała Podlaska 1996, s. $5-12$. 


\section{ADRES DO KORESPONDENCJI}

Dr Marcin Warchoła

Państwowa Wyższa Szkoła Techniczno-Ekonomiczna im. ks. Bronisława Markiewicza w Jarosławiu

Instytut Stosunków Międzynarodowych

Zakład Hotelarstwa i Animacji Czasu Wolnego

e-mail: marcin.warchola@pwste.edu.pl 